Temu Ilmiah Nasional 2020

\title{
Potensi Ekstrak Curcuma Xanthorrhiza Sebagai Terapi Pendamping Tuberkulosis
}

\author{
Hamzah Haryo Prakoso ${ }^{1}$, Andre Setiawan ${ }^{1}$, Daffa Sadewa ${ }^{1}$ \\ ${ }^{1}$ Program Studi Kedokteran, Fakultas Kedokteran, Universitas Sebelas Maret, Surakarta
}

\begin{abstract}
Tuberculosis (TB) is a disease caused by Mycobacterium tuberculosis. Most of it attacks the lungs and is still a world health problem. Therapy with a combination of drugs called Anti-Tuberculosis Drugs (OAT) has become a standard and effective cure for TB sufferers as long as it is regular and complete. However, the drawback of OAT is that it has several side effects that allow temporary drug interruption and worsening of clinical manifestations. For that we need companion therapy to overcome this. The purpose of this paper is to search and analyze literature regarding the potential of Curcuma xanthorrhizol extract as a companion therapy for tuberculosis. The method used is by searching the pubmed and google scholar databases with the keywords curcuma xanthorrhiza, curcumin, xanthorrhizol, flavonoids, Mycobacterium tuberculosis, anti-inflammatory, anti-oxidant, gastroprotective and anti-bacterial. Then the literature is selected based on inclusion and exclusion criteria. The results and discussion obtained were that curcuma xanthorrhiza has various active compounds that are useful for preventing side effects of OAT such as curcumin, xanthorrhizol, and flavonoids. Curcuma xanthorrhiza can be used as anti-inflammatory, antioxidant, gastroprotective so that side effects such as skin rashes, nausea, vomiting, abdominal pain and others can be prevented. Besides that, curcumin content in Curcuma xanthorrhiza has anti-tuberculosis activity. The conclusion is that curcuma xanthorrhiza extract can be considered as a companion drug for TB patients. It can be done further research on the potential of ginger extract to shorten the duration of TB treatment considering its benefits as anti-tuberculosis.
\end{abstract}

Keywords: tuberculosis, curcuma xanthorrhiza, herb, anti-inflammatory, hepatoprotektif, antituberculosis

\section{Pendahuluan}

Tuberkulosis (TB) masih merupakan salah satu masalah kesehatan masyarakat di dunia. Sebanyak 10 juta insiden TB dilaporkan pada tahun 2018, dengan rata-rata 130 kasus per 100.000 penduduk. Sebagian besar estimasi insiden terjadi di kawasan Asia Tenggara (44\%) dimana Indonesia menyumbangkan angka tertinggi yaitu $8 \%$. Secara global $87 \%$ kasus TB terkonsentrasi di 30 negara dengan beban TB tinggi. Salah satunya Indonesia yang menempati peringkat 3 kasus terbanyak setelah India dan China. Negara dengan beban tinggi menurut World Health Organization (WHO) didefinisikan berdasarkan 3 indikator yaitu TB,
TB/HIV dan MDR-TBC. Terdapat 13 negara yang masuk ke dalam 3 indikator tersebut termasuk Indonesia. ${ }^{1}$

Kementerian Kesehatan Republik Indonesia (Kemenkes RI) menyebutkan sebanyak 420.994 kasus terjadi pada tahun 2017, dengan prevelensi sebesar 254 kasus per 100.000 penduduk. Sementara target prevelensi TB di Indonesia adalah 245 kasus per 100.000 penduduk. ${ }^{2}$ Dalam merespon urgensinya penanggulangan $\mathrm{TB}$, Indonesia melalui Rencana Pembangunan Jangka Menengah Nasional (RPJMN) telah menargetkan prevelensi TB pada 2024 mendatang berkurang menjadi 190 kasus per 100.000 penduduk. ${ }^{3}$ Sedangkan target program 
penanggulangan TB nasional adalah eliminasi (1 kasus per 1 juta penduduk) pada tahun 2025 dan bebas TB pada tahun $2050 .{ }^{4}$

Prinsip pengobatan TB adalah dengan memberikan Obat Anti Tuberkulosis (OAT) yang merupakan minimal 4 macam obat untuk mencegah terjadinya resistensi. OAT diberikan dengan dosis yang tepat dan teratur serta diawasi oleh PMO (Pengawas Menelan Obat) sampai tuntas. Waktu pengobatan dibagi menjadi dua yaitu awal dan lanjutan. Tatalaksana untuk pengobatan TB sendiri tergolong kompleks bergantung pada kondisi individual pasien. Tetapi secara umum tatalaksana pengobatan TB memerlukan waktu $6-7$ bulan dan menggunakan kombinasi OAT lini pertama yaitu isoniazid, rifampisisn, pirazinamid, streptomisin, dan etambutol. ${ }^{4,5}$

Konsumsi OAT dalam waktu lama tentunya meningkatkan risiko terjadinya efek samping obat. Secara global angkanya berkisar $8 \%$ hingga $85 \%$. Efek samping obat lebih sering terjadi pada tahap awal dibanding lanjutan. ${ }^{6}$ Efek samping mayor yang memerlukan penghentian semua OAT anatara lain adalah ruam kulit dan kebingungan (kemungkinan masalah hati). Padahal penghentian pengobatan sementara dapat meningkatkan risiko resistensi obat. $^{4,5}$

Efek samping lainnya dapat mempengaruhi saluran cerna seperti mual sebesar $72,73 \%$, muntah $36,36 \%$, dan gangguan pencernaan lain $36,36 \% .^{7}$ Terdapat sebuah laporan kasus yang melaporkan bahwa konsumsi rifampisin tanpa dibarengi konsumsi antipiretik atau analgesik dapat menyebabkan perdarahan saluran cerna bagian atas. ${ }^{8}$ Gangguan saluran cerna pada pasien TB akan meningkatkan risiko terjadinya komplikasi malnutrisi. Sedangkan malnutrisi juga akan memperburuk manifestasi klinis dari tuberkulosis. ${ }^{9}$

Curcuma xanthorrhiza (temulawak) merupakan tanaman yang sering digunakan sebagai obat tradisional. Temulawak memiliki kandungan senyawa kimia yang aktif secara fisiologis, yaitu kurkuminoid $(1,6 \%-2,2 \%)$ dan minyak atsiri $(6 \%-10 \%)$. Kurkuminoid memiliki efek terapi sebagai antioksidan, antiinflamasi dan antitumor sehingga berpotensi untuk pencegahan dan pengobatan berbagai penyakit. Selain itu kurkumin juga memiliki efek antibakteri untuk golongan gram positif. ${ }^{10,11}$ Sementara minyak astiri memilki potensi sebagai proteksi ginjal antiinflamasi dan analgesik. ${ }^{12,13}$

Temulawak memiliki keunggulan pada sifat gastroprotektor, hepatoprotektif, nefroprotektif dan mengurangi kerusakan oksidatif akibat efek samping OAT. ${ }^{14,15,16,17}$ Temulawak juga memiliki potensi untuk dijadikan antituberkulosis. ${ }^{18}$ Dibandingkan obat tambahan terapi TB lainnya, temulawak memiliki efek samping minimal karena berasal dari bahan alami.

Salah satu upaya dari program penanggulangan TB nasional adalah pengobatan dan penanganan efek samping di Fasilitas Pelayanan Kesehatan. Penelitian dan riset oprasional di bidang obat dan obat tradisional juga merupakan salah satu upaya untuk mendukung penyelenggaran penanggulangan $\mathrm{TB}^{4}$ Oleh karena itu, penulis tertarik untuk mencari dan menganalisis mengenai potensi temulawak sebagai terapi pendamping tuberkulosis. Harapannya dengan pemberian terapi pendamping ini, pengobatan dan penanganan efek samping TB di Fasilitas Pelayanan Kesehatan dapat lebih efektif dan efesien.

\section{Metode}

Metode yang digunakan dalam penulisan ini adalah kajian pustaka. Jenis sumber yang digunakan adalah mayoritas didapatkan dari jurnal dan beberapa lainnya dari repository universitas dan buku. Pencarian pustaka dilakukan melalui database pubmed dan google scholar dengan kata kunci curcuma xanthorrhiza, curcumin, xanthorrhizol, flavonoid, Mycobacterium tuberculosis, antiinflmasi, anti-oksidan, gastroprotektif dan antibakterial. Kriteria inklusi yang digunakan adalah terpublikasi dalam kurun waktu 10 tahun terakhir dan berhubungan dengan topik pembahasan. Sedangkan kriteria eksklusi yang digunakan adalah tidak tersedia dalam bentuk full teks. 


\section{Hasil dan Pembahasan}

\section{Mycobacterium tuberkulosis}

Mycobacterium tuberculosis merupakan bakteri penyebab penyakit tuberkulosis. Bakteri ini berbentuk batang halus yang memiliki panjang 1-4 $\mu$ dan lebar 0,3-0,6 $\mu$. Dengan pewarnaan Ziehl-Neelsen akan tampak berwarna merah dengan latar belakang biru. Mycobacterium tuberculosis mempunyai struktur dinding yang sangat kompleks, yang terdiri dari asam mikolat dan polisakarida. Struktur dinding yang kompleks ini membuat bakteri Mycobacterium tuberculosis mempunyai sifat yang tahan terhadap asam (etil alcohol 95\% mengandung $3 \%$ asam hidroklorat), oleh karena itu disebut pula sebagai Basil Tahan Asam (BTA). ${ }^{19}$

Bakteri Mycobacterium tuberculosis ini tidak tahan terhadap sinar matahari langsung dan akan mati dalam waktu 1-2 jam, tetapi dapat hidup beberapa jam lebih lama ditempat yang gelap dan lembab. Sebagian besar Mycobacterium tuberculosis menyerang ke organ paru-paru $(80 \%)$ dan diluar paru paru $(20 \%) .{ }^{20}$

\section{Terapi tuberkulosis}

Dalam pengobatan pasien dengan penyakit Tuberkulosis aktif, memerlukan pengobatan kombinasi untuk mencegah perkembangan resisten. Pengobatan penyakit tuberkulosis ini terdiri dari 2 tahap. Tahap pertama (fase intensif) pasien diberikan 4 macam obat, yaitu isoniazid, rifampisin, pirazinamid dan etambutol selama 2 bulan dan untuk tahap kedua (fase lanjutan) pasien diberikan isoniazid dan rifampisin selama 4 bulan untuk memusnahkan bakteri secara keseluruhan. ${ }^{21}$

Mekanisme kerja obat isoniazid dan etambutol sebagai inhibitor sintesis dinding sel, yang mampu membunuh bakteri yang sedang tumbuh atau bakteri yang sedang memperbanyak diri. Rifampisin bekerja sebagai inhibitor sintesis RNA yang mampu membunuh bakteri yang sedang memperbanyak diri maupun tidak. Pirazinamid sebagai inhibitor proton motive force. ${ }^{19}$

\section{Mekanisme resistenti $\mathrm{OAT}$}

Mekanisme resistenti pada masing-masing obat antituberkulosis adalah sebagai berikut ${ }^{19}$

Isoniazid

Mekanisme terjadinya resistensi terhadap obat isoniazid dikarenakan terjadinya mutasi pada beberapa gen, seperti katG, inhA, ahpC, kasA dan ndh. Untuk mekanisme resistensi yang paling utama adalah mutasi gen katG dan inhA

Mutasi gen katG ditemukan pada pada kodon 315 dari gen katG ini, mutasi tersebut merupakan suatu proses subtitusi atau penggantian asam amino. Subsitusi asam amino yang paling banyak terjadi adalah subsitusi asam amino Ser315Thr.

Isoniazid akan terikat pada kompleks inhA$\mathrm{NADH}$, terbentuknya kompleks ini akan menonaktifkan enoil reductase kemudian terjadi penghambatan biosistesis asam mikolat. Mutase gen inhA terjadi pada asam amino pada tempat ikatan NADH dari inhA yang kemudian menjadikannya resistensi INH.

\section{Pirazinamid}

Sebelum melakukan fungsinya, pirazinamid perlu diubah menjadi bentuk aktifnya, yaitu asam pirazianoat oleh enzim pirazinamidase atau nikotinamidase yang dikode oleh gen pncA. Pirazinamid berkerja dalam kondisi asam untuk membunuh bakteri yang semi-dormant. Lingkungan asam dari fagolisosom, tubercle bacilli memproduksi pirazinamidase untuk mengaktivasi Pirazinamid, sehingga isolate $\mathrm{M}$. tuberculosis resisten PZA mengalami kehilangan aktivitas pirazinamid.

\section{Rifampisin}

Resistensi pada rifampisin bisa terjadi akibat mutasi dan penghapusan atau delesi pendek di gen rpoB, sehingga terjadi penurunan afinitas terhadap obat yang mengakibatkan resistensi. Sekitar $96 \%$ isolat Mycobacterium tuberculosis resisten terhadap rifampisin. Penyebabnya adalah mutasi pada daerah yang disebut "hotspot region" dari daerah inti 81-bp (rifampicin resistance-determining region atau RRDR)

Etambutol 
Mekanisme resistensi etambutol dikarenakan mutasi pada gen embB kodon 306 (embB306). Akibatnya metionin (ATG) diganti oleh valin, leusin atau isoleusin. Mutasi di embB306 menyebabkan resistensi etambutol pada berbagai tingkat namun tidak menyebabkan resistensi tingkat tinggi etambutol.

\section{Efek samping $O A T$}

Efek samping pada masing-masing obat antituberkulosis adalah sebagai berikut ${ }^{19}$

Isoniazid

Isoniazid pada umumnya jarang menimbulkan efek samping, walau bisa muncul akibat ketidak normalan enzim hepar yang menyebabkan hepatitis. Selain itu, juga dapat terjadi neuritis perifer. Efek samping lain yang dapat terjadi adalah: Paresthesia, neuritis perifer, gangguan penglihatan, hipersensitifitas, hepatotoksik, mual dan muntah, sakit kepala dan lainnya.

\section{Pirazinamid}

Efek samping yang dapat timbul saat pemakaian obat pirazinamid adalah luka liver, artalgia, anoreksia, mual muntah, dysuria, malaise, demam, urtikaria, pruritis dan eksim kulit. Penggunaan pirazinamid harus berhati-hati pada pasien dengan riwayat encok dan diabetes melitus.

\section{Rifampisin}

Efek samping yang bisa terjadi adalah influenza ringan, hepatotoksisitas dan perubahan fungsi liver. Pemakaian rifampisin dapat membuat cairan tubuh seperti keringat, air mata, urin menjadi warna oranye hingga merah.

\section{Etambutol}

Efek samping yang dapat muncul adalah neuropati optis dan hepatotoksisitas. Namun, efek samping ini bersifat reversible.

\section{Prinsip dan mekanisme kerja temulawak}

Curcuma xanthorrhiza Roxb atau biasa disebut temulawak adalah tanaman obat-obatan yang termasuk dalam suku temu-temuan (Zingiberacea). Temulawak banyak tumbuh di daerah hutan tropis dan berkembang biak dengan baik di tanah tegalan sekitar pemukiman, teutama pada tanah yang gembur, sehingga buah rimpangnya mudah berkembang menjadi besar. Temulawak masih dapat tumbuh sampai pada ketinggian tanah 1.500 meter di atas permukaan laut. 22

Temulawak memiliki berbagai senyawa aktif yang bermanafaat untuk mencegah terjadinya efek samping OAT seperti kurkumin, xanthorrhizol, dan flavonoid. Beberapa manfaat yang telah ditemukan pada senyawa-senyawa aktif tersebut antara lain:

\section{Antiinflamasi}

Mekanisme aktivitas kurkumin sebagai antiinflamasi adalah dengan menghambat produksi prostaglandin yang dapat diperantarai melalui penghambatan aktivitas enzim siklooksigenase dan kemampuannya mengikat radikal bebas oksigen yang dapat menyebabkan proses peradangan. Kurkumin juga meningkatkan glutheparon S-transferase (GST) dan menghambat beberapa faktor proinflamasi seperti nuclear factor-KB (NF-kB) dan profibrotik sitokin, dengan cara menekan kerja NF-kB maka radikal bebas dari hasil sampingan inflamasi berkurang. ${ }^{14,23}$

Xanthorrhizol memiliki aktivitas antiinflamasi berdasrakan Xanthorrhizol mempunyai aktivitas hasil docking senyawa xanthorrhizol terhadap enzim COX-1 dan COX-2. Senyawa xanthorrhizol dapat berikatan dengan kantung ikatan enzim COX-1 dan COX-2, namun lebih selektif terhadap enzim COX2. ${ }^{24}$

\section{Antioksidan}

Manfaat lain dari ekstrak temulawak adalah sebagai antioksidan. Berdasarkan penelitian Ali Rosidi (2014) ekstrak temulawak memiliki kemampuan menangkap radikal bebas DPPH 50\% pada konsentrasi 87,01 ppm. Walaupun jika dibandingkan dengan vitamin $\mathrm{C}$, aktivitas antioksidannya masih lebih rendah. Vitamin $\mathrm{C}$ memerlukan konsentrasi yang lebih sedikit yaitu 1.47 ppm. $^{25}$

DPPH (1,1-difenenil-2-pikrilhidrazil) sendiri adalah radikal bebas yang stabil di dalam larutan 
etanol. Senyawa aktif dalam temulawak mampu menangkap DPPH melalui mekanisme transfer elektron tunggal yang kemudian akan diukur berdasrkan perubahan warna. semakin banyak elektron yang dilepas warnanya akan berubah dari ungu menjadi semakin kuning-coklat. Lamanya waktu penanaman berpengaruh terhadap kadar senyawa aktif tersebut. ${ }^{26}$

Kurkumin berfungsi sebagai antioksidan yang mampu menangkap ion superoksida dan memutus rantai antar ion superoksida (O2-). Kurkumin seperti yang dijelaskan sebelumnya juga memiliki peran sebagai antiinflamasi sehingga radikal bebas yang disebabkan akibat proses inflamasi berkurang. Sedangkan xanthorrhizol menekan peroksidasi lipid yang diinduksi oleh H202. ${ }^{14,15,17}$ Sedangkan flavonoid telah ditemukan untuk menghambat aktivitas XOD dan memiliki kemampuan untuk menangkap radikal superoksida. ${ }^{27}$

\section{Gastroprotektif}

Flavonoid memiliki fungsi flavonoid menstabilisasi membran dan mempengaruhi beberapa proses metabolisme intermediet serta menginhibisi peroksidasi lipid. Flavonoid dapat meningkatkan kandungan prostaglandin mukosa dan mukus di mukosa lambung dengan menstimulasi COX-1, menunjukkan efek sitoprotekti, mengurangi sekresi asam mukosa, serta inhibisi produksi pepsinogen. ${ }^{28}$

\section{Antibakteri dan antituberkulosis}

Kurkumin

Fungsi dari kurkimin sebagai antituberkulosis adalah meningkatkan pembersihan MTB di THP-1 monosit manusia yang terdiferensiasi dan di makrofag alveolar primer. Kurkimin juga berfungsi sebagai penginduksi apoptosis dan autofagi yang bergantung pada caspase-3. Kurkimin juga memediasi fungsi seluler antiMTB ini, melalui penghambatan aktivasi faktor kappa B (NFkB) nuklir. ${ }^{19}$

\section{Xanthorrhizol}

Belum ditemukan penelitian spesifik mengenai peran xanthorrizol sebagai antituberkulosis. Namun ditemukan bahwa xanthorrizol menunjukkan aktivitas antibakteri yang paling efektif terhadap bakteri penyebab karies gigi (spesies Streptococcus), diikuti oleh bakteri penyebab periodontitis (Actinomyces viscosus dan Porphyromona gingialis). Xanthorizol juga menghambat dengan baik bakteri Gram-positif Staphylococcus aureus, Staphylococcus aureus resisten methicillin (MRSA), bakteri Gramnegatif Escherichia coli dan bakteri penyebab jerawat ropionibacterium acnes. ${ }^{29}$

Tabel 1. Peran Curcuma xhantorrhiza sebagai antituberculosis

\begin{tabular}{|c|c|l|r|r|}
\hline No & $\begin{array}{c}\text { Jenis } \\
\text { Penelitian }\end{array}$ & \multicolumn{1}{|c|}{ Hasil Penelitian } & Referensi \\
\hline 1 & In Vitro & $\begin{array}{l}\text { Ekstrak etanol C. xanthorrhiza diketahui memiliki efek antimikobakteri dengan nilai MIC } \\
1600 \\
\text { sedangkan nilai MBC 3200 } \mu \mathrm{g} / \mathrm{ml} \text { mantuk M. tuberculosis H37Rv }\end{array}$ & ml \\
\hline 2 & In Silico & $\begin{array}{l}\text { Curcuma xhantorrhiza sebagai pengobatan TB memiliki karakteristik yang bervariasi dalam } \\
\text { absopsi gastrointestinal, dapat melewati sawar darah otak dan memiliki sifat seperti obat. } \\
\text { Dalam pemeriksaan toksisitas, senyawa aktif tidak menyebabkan toksisitas ames. }\end{array}$ & [30] \\
\hline
\end{tabular}

\section{Simpulan}

Temulawak merupakan tanaman obat yang terbukti potensial dalam penatalaksanaan TB. Ekstrak temulawak mengandung senyawa aktif yang berfungsi sebagai antiinflamasi, antioksidan, gastroprotektif, antibakteri dan antituberkulosis memiliki manfaat untuk mencegah munculnya efek samping dari OAT. Ekstrak temulawak bisa digunakan sebagai antituberkulosis karena mengandung senyawa kurkumin. Ekstrak temulawak dapat dipertimbangkan untuk dijadikan obat pendamping bagi pasien TB. Dapat dikakukan penelitian lebih lanjut mengenai potensi ekstrak temulawak untuk mempersingkat lamanya pengobatan TB menimbang manfaatnya sebagi anti-tuberkulosis dan dapat diberikan dengan dosis tinggi karena merupkan bahan alami sehingga memiliki efek samping yang minimal. 


\section{Daftar Pustaka}

1. World Health Organization. 2019. Global Tuberculosis Report 2019. Geneva: World Health Organization

2. Kementerian Kesehatan Republik Indonesia. 2018. InfoDATIN: Tuberkulosis. Jakarta: Pusat Data dan Informasi Kementrian Kesehatan Republik Indonesia

3. Kementerian Kesehatan Republik Indonesia. 2018. Pokok-pokok Rencana Strategis Kementrian Kesehatan 2020 - 2024. Jakarta: Kementerian Kesehatan Republik Indonesia

4. Kementerian Kesehatan Republik Indonesia. 2016. Pedoman Nasional Pengendalian Tuberkulosis. Jakarta: Kementerian Kesehatan Republik Indonesia

5. Badan Pengawas Obat dan Makanan. 2014. Antituberkulosis. Buku Informatorium Obat Nasional Indonesia (IONI). Jakarta: Pusat Informasi Obat Nasional.

6. Prasad R, Singh A, Gupta N. Adverse drug reactions in tuberculosis and management. Indian J Tuberc. 2019;66(4):520-532. doi:10.1016/j.ijtb.2019.11.005

7. Farhanisa, Untari EK, Nansy E. Kejadian Efek Samping Obat Anti Tuberkulosis (OAT) Kategori 1 Pada Pasien TB Paru Di Unit Pengobatan Penyakit Paru-Paru (UP4) Provinsi Kalimantan Barat. 2014;2(2337):1-2.

8. Zargar SA, Thapa BR, Sahni A, Mehta S. Rifampicin - Induced Upper Gastrointestinal Bleeding. Postgrad Med J. 1990;66(774):310-1

9. Schaible U, Kaufmann S. Malnutrition and infection: Complex mechanisms and global impacts. PLoS Med. 2007;4(5):115

10. Noorafshan, A., \& Ashkani-Esfahani, S. (2013). A review of therapeutic effects of curcumin. Current pharmaceutical design, 19(11), 2032-2046.

11. Dermawaty, D. E. (2015). Potential extract curcuma (Curcuma xanthorrizal, Roxb) as antibacterials. Jurnal Majority, 4(1).

12. Hakim, R., Bintari, Y. R., \& Damayanti, D. S. (2018). Studi Insilico Potensi Minyak Astiri dan Ekstrak Etanol Daun Annona muricata Sebagai Calon Herbal Terstandart Untuk Analgesik dan Antiinflamasi. Jurnal Kesehatan Islam: Islamic Health Journal, 7(01).

13. Sundararajan R, Bharampuram A, Koduru R. A Review on Phytoconstituents for Nephroprotective Activity. Pharmacophore. 2014;5(1):160-82. Available from: www.pharmacophorejournal.com/

14. Pratama, P. B., Ismail, A., \& Witjahjo, R. B. (2019). Pengaruh Pemberian Ekstrak Temulawak (Curcuma Xanthorrhiza) Dosis Bertingkat Terhadap Gambaran Mikroskopis Hepar Mencit Balb/C Jantan Yang Diinduksi Rifampisin. Jurnal Kedokteran Diponegoro, 8(3), 1026-1036.

15. Amrizal, R., Witjahjo, R. B., \& Ismail, A. (2019). Pengaruh Pemberian Ekstrak Temulawak (Curcuma Xanthorrhiza) Dosis Bertingkat Terhadap
Gambaran Mikrokropis Testis Mencit Balb/C Jantan Yang Di Induksi Rifampisin. Jurnal Kedokteran Diponegoro, 8(3), 1050-1060.

16. Paramita, T. M., Witjahjo, R. B., \& Ismail, A. (2019). Pengaruh Pemberian Ekstrak Temulawak (Curcuma Xanthorrhiza) Dosis Bertingkat Terhadap Gambaran Mikroskopis Gaster Mencit Balb/C Jantan Yang Diinduksi Rifampisin. Diponegoro Medical Journal (Jurnal Kedokteran Diponegoro), 8(1), 531-542.

17. Shakti, S. W., Ismail, A., \& Witjahjo, R. B. (2019). Hpengaruh Pemberian Ekstrak Temulawak (Curcuma Xanthorrhiza) Dosis Bertingkat Terhadap Gambaran Mikrokropis Ginjal Mencit Balb/C Jantan Yang Diinduksi Rifampisin. Diponegoro Medical Journal (Jurnal Kedokteran Diponegoro), 8(1), 509-522.

18. Ngadino, S., Koerniasari, E., \& SA, S. (2018). Evaluation of antimycobacterial activity of Curcuma xanthorrhiza ethanolic extract against Mycobacterium tuberculosis H37Rv in vitro. Veterinary world, 11(3), 368.

19. Irianti, Dr. Rer. Net. T, Kuswandi, Yasin, Dr. N. M, Kusumaningtyas, R. A. 2016. Mengenal AntiTuberkulosis. Yogyakarta

20. Dotulong, J. F. J., Sapulete, M. R. and Kandou, G. D. (2015) 'Hubungan Faktor Risiko Umur, Jenis Kelamin Dan Kepadatan Hunian Dengan Kejadian Penyakit Tb Paru Di Desa Wori Kecamatan Wori', Jurnal Kedokteran Komunitas Dan Tropik, 3(2), pp. $57-65$

21. Rimporok, A. and Budiarso, F. (2019) 'Uji Anti Bakteri Ekstrak Daun Tanaman Kaki Kuda (Centella Asiatica L. Urban) Sebagai Tumbuhan Obat Anti Tuberkulosis', Jurnal Biomedik: Jbm, 12(1), pp. 31-37. doi: 10.35790/jbm.12.1.2020.27003

22. Sina, Y. M. 2013. Sejuta Khasiat Herbal Temulawak: Penangkal Segala Penyakit \& Penjaga Stamina Tubuh. Jakarta: Diandra Primamitra.

23. Sujono, T. A., Patimah, R., \& Yuliani, R. (2012). Efek Antiinflamasi Infusa Rimpang Temu Putih (Curcuma zedoaria (Berg) Roscoe) Pada Tikus Yang Diinduksi Karagenin. Biomedika, 4(2).

24. Dinata, D. I., Suryatno, H., Musfiroh, I., \& Suherman, S. E. (2014). Simulasi Docking Molekuler Senyawa Xanthorrhizol sebagai Antiinflamasi terhadap Enzim COX-1 dan COX-2. Indonesian Journal of Pharmaceutical Science and Technology, 1(1), 8.

25. Rosidi, A., Khomsan, A., Setiawan, B., Riyadi, H., \& Briawan, D. (2014). Potensi Temulawak (Curcuma xanthorrhiza Roxb) Sebagai Antioksidan. In Prosiding Seminar Nasional \& Internasional.

26. Rosiyani L. 2010. Evalusi Perubahan Metabolit Pada Temulawak Dengan Waktu Tanam Berbeda. [Skripsi]. Bogor (ID) : Institut Pertanian Bogor

27. Kaurinovic, B., \& Vastag, D. (2019). Flavonoids and phenolic acids as potential natural antioxidants. In Antioxidants. IntechOpen. 
28. Bintari, G. S., Windarti, I., \& Fiana, D. N. (2013). Temulawak (Curcuma xanthorrhiza Roxb) Sebagai Pencegah Kerusakan Mukosa Lambung. Jurnal Majority, 3(5).

29. Oon, S. F., Nallappan, M., Tee, T. T., Shohaimi, S., Kassim, N. K., Sa'ariwijaya, M. S. F., \& Cheah, Y. H. (2015). Xanthorrhizol: a review of its pharmacological activities and anticancer properties. Cancer cell international, 15(1), 100.

30. Aristyani, S., Nur, M. I., Widyarti, S., \& Sumitro, S. B. (2018). In silico study of active compounds ADMET Profiling in Curcuma xanthorrhiza Roxb and Tamarindus indica as Tuberculosis Treatment. Jurnal Jamu Indonesia, 3(3), 101-108. https://doi.org/10.29244/jji.v3i3.67 